\title{
Blended Learning Strategies as Knowledge Management in Underdeveloped Area
}

\author{
Priska Vasantan \\ \{priska@shantibhuana.ac.id\} \\ Shanti Bhuana Institute, Jl. Bukit Karmel no. 1, Bengkayang, West Borneo
}

\begin{abstract}
This study was conducted in Bengkayang city, one of the underdeveloped districts and bordered by Malaysia that human resources have poor knowledge, hard skills, and soft skills such as computer, mathematics, language skills and spiritual. This study investigates the blended learning strategies as knowledge transfer in higher education in an underdeveloped area that we present the result from 6 final year student's blended learning experience, and 117 students who registered at higher education. Methodological trends described in the term qualitative phenomenology of 3 final year student's blended learning experience by Moustakas. The result of this study shows that the implementation of blended learning strategies influenced by local wisdom, learning style, and learning methods. The local wisdom such as communal, the availability of food in nature affects the lifestyle of students; learning style such as visual, auditory, and kinesthetic affects how the students learn; and learning methods such as drill method affects study habits and increase student knowledge.
\end{abstract}

Keywords: blended learning, knowledge management, phenomenology Moustakas, learning style.

\section{Introduction}

Bengkayang is one of the underdeveloped areas in West Borneo which majority of the population is Dayak. According to the village minister, development, and underdeveloped area [17], since July 31, 2019, Bengkayang including the area that was left out of backwardness in the economic, human resources, infrastructure, regional financial capacity, accessibility, and regional characteristic. However, the impact of the underdeveloped area in Bengkayang still felt mainly on the quality of students. According to Bengkayang People's Welfare Statistics 2019 [2], there is $16,96 \%$ elementary school students, 4,87\% junior high school student, and 6,11\% senior high school students. Based on this data, there is a decrease in the number of students continuing senior high school because of many factors such as awareness of the importance of education, quality of the teacher, 
local wisdom [28,29]. Because of that, increasing the quality of human resources takes time and needs a knowledge management strategy.

The limited quality of these resources is the benchmark for this study. Highlighting this limitation, the researcher wants to find a blended learning strategy as knowledge management that is used to improve the quality of knowledge transfer at Shanti Bhuana Institute. Shanti Bhuana Institute is the only college with an undergraduate degree in Bengkayang. This campus implements a blended learning system, which is a combination of e-learning and face-to-face with the hope that students will get to know the world of e-learning with various forms of teaching provided so that students are familiar with the internet. Thus, students indirectly improve their skills in ICT (Information Communication Technology), computers, English, and so on.

The blended learning strategy greatly influences the knowledge transfer process in knowledge management. Based on previous research [28,29], the successful application of blended learning in the Holy Trinity Community is influenced by the existing local wisdom. In this study, the researcher wanted to find the right blended learning strategy to be used at Shanti Bhuana Institute by paying attention to the factors that influence the success of blended learning, for example, local wisdom, learning styles, and so on.

Since the 1990s, knowledge management is one of the important disciplines to explain that knowledge created, developed, implement in organizational learning and innovation $[11,21,25,26]$. Knowledge is an important source to the education world that the asset of the knowledge is intellectual capital. The intellectual capital has often called human capital, organizational capital, and social capital [9]. One of component the denominator intellectual capital as human capital is knowledge, education, and training [15]. Therefore, it can be said that knowledge as intellectual capital is a very important asset and need to be managed properly. According to Edna \& Tuvya [23], intellectual capital divides into two major components that are human capital (knowledge and skills individual) and structural capital (organizational capabilities that support an individual's productivity). Therefore, knowledge management strategy is very important to build individual knowledge through learning.

Learning is an important knowledge transfer process for the quality of human resources, for the successful educational system. Definition of the learning is an effective process for students to transform words and explanations by the teacher or the presentation into passable skills such as problem-solving[3]. One of the 
definitions learning by Kolb [7], learning is the process of creating knowledge and Kolb described the relation between learning styles (diverging, assimilating, converging and accommodating) with five levels of behavior (personality types, educational specialization, professional career, current jobs, and adaptive competence). Knowledge management plays an active role in the learning process that the success of the learning process depends on the knowledge transfer strategies. According to Bateson [27], there are two kinds of learning is learning I (single-loop learning) is knowing how to solve the problem, learning II (doubleloop learning) is building new premises (paradigm, schemata, mental models, or perspectives) to put aside existing one. The Nonaka and Takeuchi perspective [22], the creation of knowledge certainly involves interaction between these two kinds of learning, which forms a kind of dynamic spiral. According to Becheik [2], the main determinant knowledge transfer process in education such as linkage agents is the important actors in knowledge transfer to help the easier ways of adopting knowledge by practitioners. The factors the effectiveness process is divided into three major categories are the attribute of knowledge to transfer, the actor who involved in the process, and the process mechanism.

The research done in the past year is the learning style of the student from a different career that very important thing to drive the quality of teaching [30]. In this study, the researcher investigates the blended learning strategies as knowledge management that influenced by local wisdom, learning style, learning methods. The strategies of blended learning which used in this study are drill methods, learning media, discussion, game education, etc. In the past research by Alammary, etc. [1] that is three design approaches of blended learning based impact blends. The other past research by Money, et al [19] the blended learning strategies is curriculum transition on the higher school from student's viewpoint.

Viloria's research focuses on the student's learning According to Pratchett, $G$ Young, 2018 the kinds of learning styles are activist, reflector, theorist, and pragmatist. According to Kolb[14], that the learning style based the experiential learning is 9 learning styles [30]. The invention of Viloria in another research, educational data mining which one tool to help the teacher to know the student's learning styles [31]. Learning styles in higher education for improving the quality of education at university. In this research, Viloria found that in the relationship between learning styles and career have statistically significant differences between activist, theorist, and pragmatist learning styles. The result about to with concerning learning styles and gender that male students showed higher averages in reflector 
learning style and the female showed higher scores in pragmatist, theorist, and activities styles.

\section{$2 \quad$ Literature review}

\subsection{Organizational Learning and Knowledge Management}

Chiva, et al [4,5] state there are three approaches to learning that is individual, social learning, and mindful learning perspective. The individual and social learning approach including the traditional approaches. The first approach, individual learning-cognitive possession knowledge could be divided into three groups according to Merriam and Caffarella [18], learning in adulthood such as the adult learner, the nature of the learning process that is:

1. The theory behaviorist [12], such as:

a. Connectionism (S-R Bond) by Thorndike, one of the laws that his findings are the law of exercise describes that connectionism between stimulus and responses more tightens up if often trained.

b. Classical Conditioning by Ivan Pavlov, one of the laws that his findings are the law of respondent conditioning describes that two stimuli (one of them is reinforcer) presented simultaneously then the reflects and stimulus will be increased.

c. Operant conditioning by Skinner describes the operant with the strong stimulus, the power of the operant will be increased.

2. The cognitivist, Kohler [13], a gestalt psychologist, suggested that learning occurs in the form of insight. The cognitive perspective of organizational learning suggested the organizations can learn and organizational learning to be a type of individual learning

3. The humanists, Maslow, and Roger [8] said that the success of educational systems depends on the ability to involve the students in the learning process and understand the meaning in the acquisition of knowledge.

This approach that the individual perspective that learning as an individual phenomenon and consequently to understand the individual learned by the organization. Based on the behaviorist theory this approach can be included in the drill method. To improve the student's performance in one aspect such as to operate tools of e-learning (Learning Management Systems/LMS and Academic Information Systems/AIS), the students need to devote so much attention to the one 
aspect. According to Scott H. Young [32], drills resolve this problem that the students can focus the cognitive resources on a single aspect.

The second approach, social learning by Albert Bandura with reward and punishment will motivate individuals to think and decide selected social behavior. The social approach perspective that learning as a social phenomenon and consequently to understand the organization learned by communities. Meliono [16] suggest Nusantara thought, local wisdom, multiculturalism is appropriate teaching material [16]. Local wisdom is the values as a guide that is followed by a community that sometimes appears the symbols in people's interaction. According to the Vasantan's research [29] about local wisdom of Dayak communities in West Borneo that is communal communities, food available in nature influences how student studies like discussion, group study, instantly life, etc. This local wisdom also influences the final college student's learning style that is $60 \%$ kinesthetic student.

The third approach, Chiva's finding of mindfulness [5] that knowledge inhibits learning. As the Bengkayang people which one of the districts has left out backwardness in 2019, but the fact Bengkayang is still not completely removed from its lag, especially the quality of human resources. Therefore, the majority of knowledge possessed by human resources helps the learning process in this college because students more easily believe in receiving new information provided.

\subsection{Knowledge Management}

Krishnamurti [5] said the knowledge is passed. The knowledge is tending to enslave the human way of thinking. Learning is a process to learn something in the future and the things learned become knowledge. Learning is not listening to the knowledge, but the important things in learning are conscious, mindful, and humble (not know) that Chiva said knowledge inhibit learning (mindfulness). Girad and Girard [10] state that the definition of knowledge management is the process of creating, sharing, using the knowledge or information in the organization.

According to Collins 2010, [6] tacit knowledge exists in various lives in a range of education such as philosophy, psychology, sociology, management, and economics dan di artificial intelligent world. Collins said the idea of the tacit is practical the idea of the explicit, examples the efficient way to fulfill the need to transfer the tacit to other people is telling to other people with the book, internet, and other media. 


\section{$3 \quad$ Method}

\subsection{Sample and Population}

This study was conducted using a purposed sample Patton [24], the participant focused on selecting college student who best represents their population and describes the researcher's phenomenon. The research sample consisted of 8 final year college students as the main participants and 112 college students who registered in Shanti Bhuana Institute. The main participants included 4 Management college students and 4 Entrepreneur college students. The support participants included 65 Management college students and 47 Entrepreneurship college students, with 0,5-3 years of experience with blended learning methods. The Management college students included 7 final year students with 3 years of experience, 15 students with 3 years of experience, 26 students with 2 years of experience, and 25 students with 0,5 years of experience. The Entrepreneur college students included 5 students with 4 years of experience, 20 students with 3 years of experience, 8 students with 2 years of experience, and 14 students with 0,5 years of experience. The final year students study 1 year with $100 \%$ face to face and 3 years with blended learning.

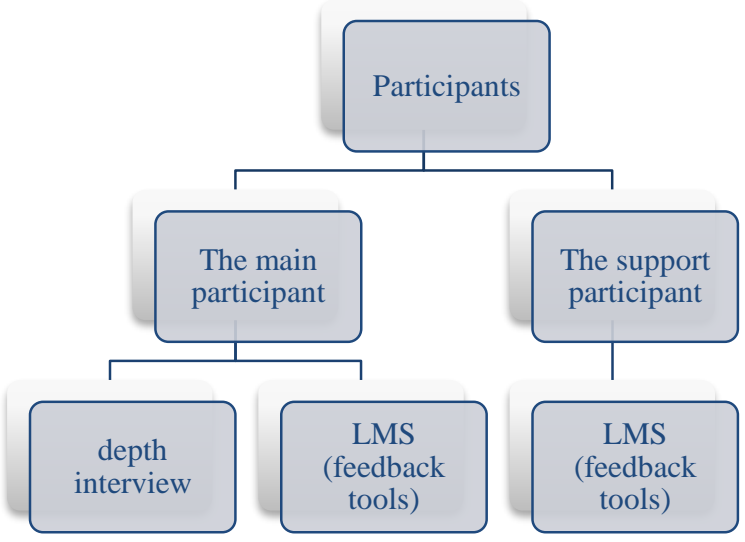

Figure 1. Sample and Population 
Table 1. The Main Participant

\begin{tabular}{cccc}
\hline Pseudonyms & Hometown & Learning style & Study program \\
\hline Teddy & Malang, East Java & Visual & Entrepreneur \\
Esi & Bandol, West Borneo & Auditory & Entrepreneur \\
Eddy & Bengkayang city, West & Kinesthetic & Entrepreneur \\
Dina & Borneo & Visual & Management \\
Ghea & Maumere, Flores & Auditory & Management \\
Pika & Banggau, West Borneo & Kinesthetic & Management \\
\hline
\end{tabular}

\subsection{Research Procedure}

In this study, data were collected by 3 years in the qualitative method with transcendental-phenomenology [20]. The study used as an illustration is blended learning in the ongoing study of sustained strategies of blended learning in Management Science High School Shanti Bhuana (Shanti Bhuana Institute) in Bengkayang. Since the middle year 2017, Shanti Bhuana Institute has provided a Learning Management System (LMS) and Academic Information System (AIS) for college students who study in Shanti Bhuana Institute. All college students are trained in computer skills and English skills every semester with drill methods. The basic approach in Shanti Bhuana Institute is 8 final year college students for three years and 49 student entrepreneur study program and 68 student management study program who registered in 2019-2020 carried out at blended learning experiences. (Fig. 1)

The researcher had been observed and interviewed the participant who final year college students with depth interviewed about the experience of blended learning and face to face learning without e-learning. The observation of participant was since 2017, the time which the blended learning began. Each interviewed lasted 10-30 minutes several times. On the other hand, data of the support participant had been collected with questionnaires about student satisfaction in LMS about study in Shanti Bhuana Institute especially blended learning program which performed by student affairs of Shanti Bhuana Institute. The question is about suggestions for the blended learning system. 


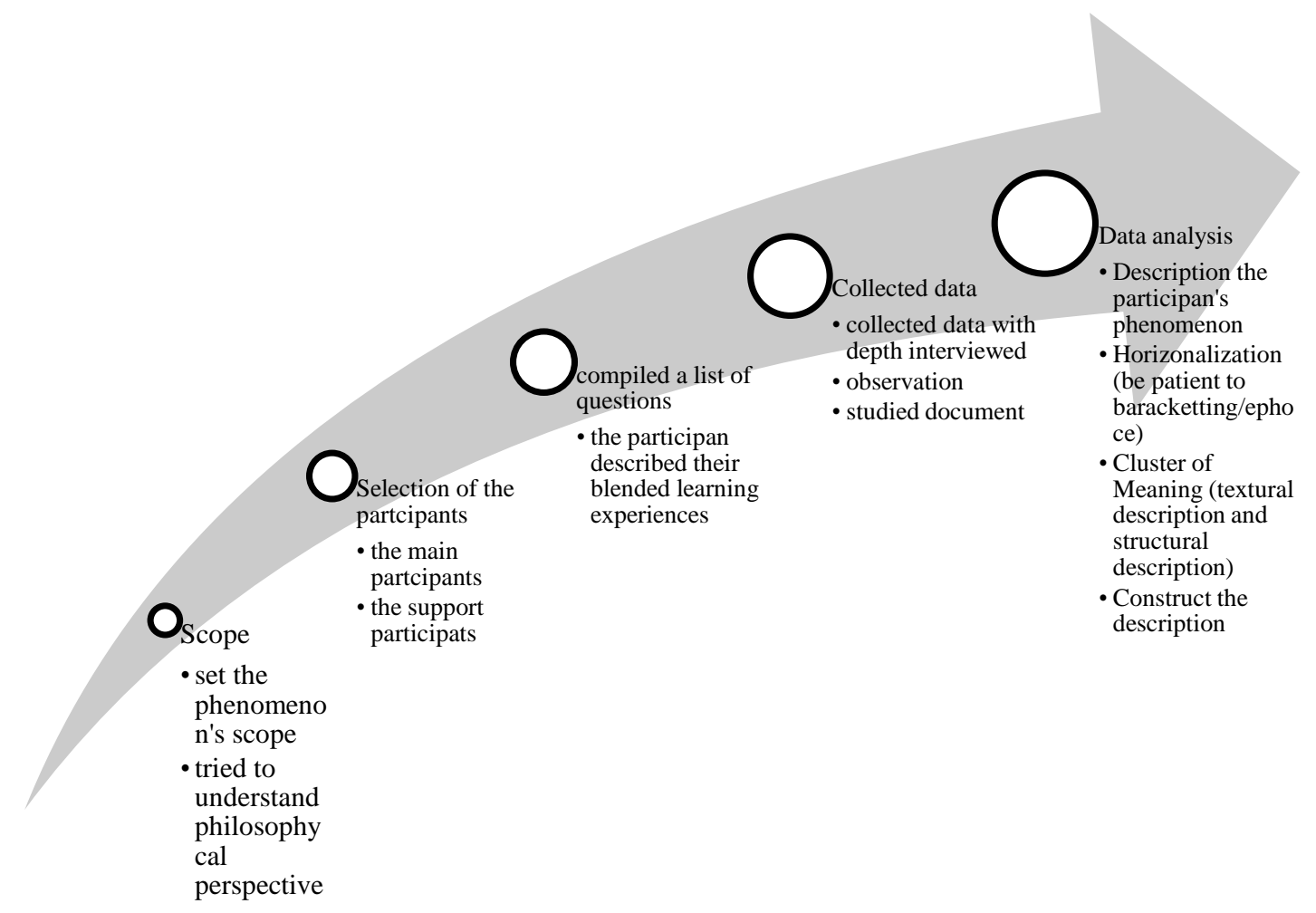

Figure 2. Research Procedure

The important procedures performed in this study had 5 steps (fig. 2) that are:

a) Scope

The determination scope of this study aims to understand the philosophical perspective by determining phenomenology to be studied

b) Selection of the participant

This study used the purposed sample (Patton) that the main participant who has the specific data that the researcher needs and the support participant aims to provide reinforcement data from the main participant. Therefore, the criteria of the main participant were final year college students who have a lot of experience, a different hometown to differentiate local wisdom that they had, the different learning styles, and represent their program study. The support 
participants are a majority college student in Shanti Bhuana Institute who live in Bengkayang regency, so they have the same local wisdom and knowledge.

c) Compiled a list of question

The question that is given must be direct the participant to tell the experience about blended learning.

d) Collected data

The data collected from the main participant phenomenology through depth interview and observation for three years. While the data collection from the support participant was obtained from the questionnaire in Learning Management Systems (LMS).

e) Data analysis

1) The early-stage

The researcher described the results of interviews and observation then transcribe them in writing.

2) The horizontalization stage

The researcher has inventoried statements that relevant to the topic from the results of transcription. In this stage, the researcher must be avoided subjectivity assessment with bracketing/epoche the data obtained from interviews.

3) The cluster of meaning stage

Classification the statements into themes or units of mean, and set overlapping or repetitive statements. In this stage, must be done:

a. Textural description (written the individual experiences)

b. Structural description (written how the phenomenon experienced by the individual)

The researcher looks for all the meaning derived from the reflection in the form of opinion, judgments, feelings, expectations of the subject about the phenomenon experienced.

4) The essential description

The researcher constructs a thorough description of the meaning and essence of the subject

\subsection{Data Analysis}

The essence of the experiences shared by the main participant surrounded about the difference, the advantage of blended learning and the conventional learning, the learning style, and learning media, buddy program. The next step in 
this research is outlined in this article, using transcendental phenomenology, which builds on the first inquiry. This study sought blended learning strategies that useful for learning in the underdeveloped areas especially at Shanti Bhuana Institute, Bengkayang city that is influenced by local wisdom, learning style, and learning methods. We studied the same six final year students that they have been a blended learning experience for 3 years and pure face-to-face learning for 1 year while college. Their study program and learning style are shown in table 1 . This study has two key questions that Moustakas recommends that phenomenologist asks: What were their experiences with how to learn that they enjoyed? And in what context or situations di they experience it? This study used pseudonyms to protect their identities. Transcripts from the interviewer were analyzed for codes and themes followed Cresswell [7].

\section{$4 \quad$ Findings and Discussion}

This study took place in Shanti Bhuana Institute, Bengkayang the majority of the college students are Dayak.

Significant statement of the main participant

Teddy (Chinese, Malang, East Java, Visual, entrepreneur study program)

I have no difficulty learning LMS for the first time because I am accustomed to using computers and the internet in the past when I was living in Java. I am very love watching the movie or video that I was got many things useful for me. The LMS is very helpful to study that I can download lecture notes or PPT. I prefer to study alone and study with a mind map, watch youtube.

Eddy (Dayak, Bengkayang, kinesthetic, entrepreneur study program)

I graduated from high school in Sintang, Sanggau Regency. I used to use a laptop in high school.

I prefer to learn face-to-face in a relaxed manner, may drink coffee, not too serious, there is practice and sharing so that I am not bored. In my opinion, the buddy program is very important because I study together.

The existence of LMS and AIS helped me, although the first time I had difficulty to operate LMS and AIS, but I had open and learn from LMS and AIS many times, and now it is very easy for me. If there are no LMS and AIS, I don't know anymore because it is very difficult for example with LMS, I usually download material and assignments and upload tasks when in the past to get the 
material I had to use a flash. For now, I can directly read and upload assignments on my cellphone. Likewise, if before AIS was there if you wanted to ask for ICP validation you had to ask for a stamp and queue first if there was AIS ... I just input and then wait for validation and I usually do it wherever and whenever.

Eddy has experienced with culture change

Esi (Dayak, Bandol, Landak regency, auditory, entrepreneur)

I prefer to study face to face with a relaxed situation, not tense, calm, and study with my friends like a buddy program because it is not boring and gets a lot of input from my friends. I prefer my lecturer gave me examples from the real world. I prefer to discuss it with my friend because we can be sharing knowledge and relax.

For the first time I used a laptop provided by campus, I am very confused because I am not familiar with a laptop, but I must operate because the majority of my coursework must be typed in word and excel. Time after time, I get used to using the laptop.

One year later, we use LMS and AIS, the tools for learning with media online. Although initially LMS and AIS are difficult for me, sooner or later that tools are very easier to used and these tools are very useful to upload and download the lecture notes.

Pika (Dayak, Tembawang Bale, Landak regency, Kinesthetic, Management)

In the classroom, I prefer the lecturer to teach me with a discussion method, in variation place to study but I cannot study very longer. If study, I prefer to study with my friends. I love games education, it makes me enjoyed studying. I loved to study with PowerPoint and video.

In the beginning, I know LMS and AIS, I am very confused to use it, because it is very new for me but I must practice using this tool because my coursework, lecture notes are uploaded. So time after time, I understand and easier to use these tools and very helpful.

I love to live in a dormitory because many friends can discuss many things.

Ghea (Dayak, Bengkayang, Auditory, Management)

I come from Sekadau, Sanggau regency. I have been in Saudi Arabia for 2 years after I graduate from the nurse academy. I married and stay in Bengkayang. In the classroom, I very much love learning by discussion because increased my knowledge with sharing knowledge. And the lecturer as mediator. I am very interested in practice in the real world because I met many people that I had learned about anything like culture, temperament, and local wisdom. 
LMS and AIS are very helpful and simplified learning systems. In the beginning, I must learn and try how to operate this tool, and finally, it is very easier to use.

If I am not married, I loved to stay at a dormitory, because I'll meet many characters and I'll learn how to live together with my weakness. Ghea is used to using a laptop and communication with English. She has experienced culture change.

Dina (Atambua, Visual, Management)

I come from Atambua and I had been a mission volunteer in Bandol, Landak regency. For the first time, I have to adapt to the Dayak culture, especially in terms of interaction with others. We gather only in the context of family gatherings and are not allowed to eat food from strangers, but this is the opposite of the Dayaks. I don't like hanging out with friends without a clear purpose. At Atambua, I'm used to searching for information on the internet

I like learning to be alone and avoid the crowd by reading and then writing again by marking.

LMS helped me in the learning process. For the first time, I was confused and asked several people how to use this tool. If I have to collect assignments, I just open the LMS and upload it and don't need to find a lecturer for the collection process. For me, LMS is very effective and efficient because it is not bound by time and place.

Meaning Units or Themes

The things that affect blended learning are:

\begin{tabular}{|c|c|c|}
\hline $\begin{array}{l}\text { Local } \quad \text { wisdom } \\
\text { (Dayak) }\end{array}$ & $\begin{array}{l}\text { - The relaxed manner may drink coffee, not too serious } \\
\text { - sharing (discussion) } \\
\text { - } \text { study with my friends, discussion } \\
\text { - I love to live in the dormitory because many friends can discuss } \\
\text { - I loved to stay at the dormitory } \\
\text { - relax situation, not tense, calm and study with my friend } \\
\text { - I prefer to discuss it with my friend because we can be sharing } \\
\text { knowledge }\end{array}$ & $\begin{array}{l}\text { - Accustomed } \\
\text { to living } \\
\text { from nature } \\
\text { - communal }\end{array}$ \\
\hline $\begin{array}{l}\text { Local wisdom } \\
\text { (Dayak) Entrepreneur } \\
\text { study program }\end{array}$ & - There is always a notification between lecturer and student. & $\begin{array}{l}\text { - Accustomed } \\
\text { to living } \\
\text { from nature }\end{array}$ \\
\hline $\begin{array}{l}\text { Local wisdom } \\
\text { (Chinese, East Java) }\end{array}$ & $\begin{array}{l}\text { - I was accustomed to using computers and the internet in the } \\
\text { past when I was living in Java. }\end{array}$ & - individual \\
\hline
\end{tabular}




\begin{tabular}{|l|l|l|}
\hline & $\bullet$ I prefer to study alone & \\
\hline Local wisdom (Flores) & $\bullet$ I don't like hanging out with friends without a clear purpose. \\
& $\begin{array}{l}\text { We gather only in the context of family gatherings and are not } \\
\text { allowed to eat food from strangers, but this is the opposite of } \\
\text { the Dayaks. }\end{array}$ & $\bullet$ individually \\
& I like learning to be alone and avoid the crowd & \\
\hline
\end{tabular}

According to Vasantan 2016 [28], the Dayak has 3 local wisdom namely living with the availability of nature so accustomed to living quietly and waiting for the harvest, as well as often the food is already available in nature. Second, the majority of Dayak have communal society thus having the impact of the learning group, and the third, the impact from the lagging telecommunication signal.

According to the Dayaknese student's experiences, Eddy said that I prefer to learn face-to-face in a relaxed manner, may drink coffee, not too serious, there is practice, and sharing so that I am not bored. In my opinion, the buddy program is very important because I study together. "I prefer to study face to face with relax situation, not tense, calm, and study with my friends like buddy program because it is not boring and get a lot of input from my friends.", shares Esi. Pika said that I prefer to study with my friends. Ghea shares that "If I am not married, I loved to stay at the dormitory, because I'll meet many characteristics and I'll learn how to live together". Eddy, Esi, Pika, and Ghea are the Dayak people, they have the same opinion that they prefer to study in a relaxed and calm situation and study together.

Different from Teddy said "I prefer to study alone" and "I don't like hanging out with friends without a clear purpose. I like learning to be alone and avoid the crowd" shares Dina. Teddy came from Malang City, East Java that the people have local wisdom to be individual because of bustle. On the other hand, Dina came from Atambua, Flores that one of the local wisdom is very careful of foreigners so Dina used to be alone.

Therefore, the knowledge transfer must pay attention to local wisdom. In this study, the researcher used Dayak's local wisdom that communal and relaxed lifestyles.

2. Learning style

\begin{tabular}{|l|l|}
\hline Visual & $\begin{array}{l}\text { I am very love watching the movie or video } \\
\text { study with a mind map watches youtube } \\
\text { by reading and then writing again by marking. }\end{array}$ \\
\hline Auditory & I prefer to discuss with my friend because we can share knowledge of each other \\
\hline
\end{tabular}




\begin{tabular}{|l|l|}
\hline & $\begin{array}{l}\text { I very love to learning by discussion because increased my knowledge with sharing } \\
\text { knowledge }\end{array}$ \\
\hline Kinesthetic & $\bullet$ practice and sharing \\
& $\bullet$ discussion method, in variation place, to study but I cannot study very longer \\
& I love games education, it makes me enjoyed studying.
\end{tabular}

According to Lucimar (An Integrative Debate) if the students know their learning style can help them to enjoy the learning by prioritizing their learning activities. Sucheta (Adaptive User) that interface of Moodle as a tool a learning system influenced the virtual learning styles.

The visual learners said: "I am very love watching the movie or video"; "study with a mind map, watches youtube", and the other learner said, "by reading and then writing again by marking." Therefore, in the study by LMS, the visual learner prefer to study with youtube, video, picture, and at the classroom/face-toface, the visual learner prefers to make mind mapping, reading, and writing.

The auditory learners said: "I prefer to discuss with my friend because we can share knowledge" and "I very love to learning by discussion because increased my knowledge with sharing knowledge". Therefore, in the study by LMS, the auditory learner prefer to study with discussion, and at the classroom/face-to-face, the auditory learner prefers discussion and hear the friend's sharing.

The kinesthetic learners said: "practice and sharing"; "discussion method, in variation place to study but I cannot study very long", and "I love games education, it makes me enjoyed studying". Therefore, in the study by LMS, the kinesthetic learner prefer to study with games education, practice, and at the classroom/faceto-face, the kinesthetic learner prefers games, study outdoor, and practice in the real world.

Blended Learning Strategies

1. Learning Media

\begin{tabular}{|l|l|}
\hline $\begin{array}{l}\text { Management } \\
\text { study } \\
\text { program }\end{array}$ & $\begin{array}{l}\text { Email assignments are very effective when LMS is slow or has signal problems } \\
\text { - The calendar in the LMS is underused for the lecture material agenda } \\
\text { - So that students can better understand the lectures that take place via WhatsApp so that } \\
\text { it is easier to access }\end{array}$ \\
\hline Discussion & $\begin{array}{l}\text { My suggestion is for lecturers not to overburden students with assignments, especially } \\
\text { without being balanced with the material. Maybe lecturers need to provide material in } \\
\text { the form of scheduled discussions so that students are ready for discussion by searching } \\
\text { the internet before the discussion } \\
\text { - Give more material or discussion }\end{array}$ \\
\hline
\end{tabular}




\begin{tabular}{|l|l|}
\hline & $\begin{array}{l}\text { My suggestion is for lecturers not to overburden students with assignments, especially } \\
\text { without being matched by the material. Maybe lecturers need to provide material in the } \\
\text { form of scheduled discussions so that students are ready for discussion by searching the } \\
\text { internet before the discussion }\end{array}$ \\
\hline
\end{tabular}

2. Learning Methods

\begin{tabular}{|l|l|}
\hline Visual & $\begin{array}{l}\text { I am very love watching the movie or video } \\
\text { study with a mind map watches youtube } \\
\text { by reading and then writing again by marking. }\end{array}$ \\
\hline Auditory & $\begin{array}{l}\text { I prefer to discuss with my friend because we can share knowledge of each other } \\
\text { I very love to learning by discussion because increased my knowledge with sharing } \\
\text { knowledge }\end{array}$ \\
\hline Kinesthetic & $\begin{array}{l}\bullet \text { practice and sharing } \\
\text { discussion method, in variation place, to study but I cannot study very longer } \\
\text { - I love games education, it makes me enjoyed studying. }\end{array}$ \\
\hline
\end{tabular}

The learning media are tools used for the implementation type of the learners as visual, auditory, and kinesthetic that have been described in the previous explanation of the learning style.

\section{Drill Methods}

\begin{tabular}{|c|c|}
\hline $\begin{array}{l}\text { The main } \\
\text { participant }\end{array}$ & $\begin{array}{l}\text { - many times, and now it is very easy for me } \\
\text { - Time after time, I get used to using the laptop } \\
\text { - Although initially LMS and AIS is difficult for me, sooner or later that tools very easier to } \\
\text { use } \\
\text { - I must practice used this tool because my coursework, lecture notes are uploaded. } \\
\text { - I loved to study with PowerPoint and video. } \\
\text { - I must learn and try how to operate this tool } \\
\text { - For the first time, I was confused and asked several people how to use this tool. }\end{array}$ \\
\hline $\begin{array}{l}\text { Management } \\
\text { Study } \\
\text { program }\end{array}$ & $\begin{array}{l}\text { 1. LMS that are often overloaded so that they are sometimes difficult to access } \\
\text { 2. My suggestion is that the AIS / LMS server must remain fully activated, except Sunday. } \\
\text { 3. My suggestion is expected that LMS and also AIS will no longer experience frequent } \\
\text { disturbances because it is very influential for students } \\
\text { 4. For the system in the LMS is good, but if possible the size of the shipment is enlarged or } \\
\text { added, making it easier for students to make deliveries in the form of video assignments } \\
\text { whose size exceeds the limit in the LMS. thanks. } \\
\text { 5. I suggest that the server admin pay more attention to opening and closing hours for the } \\
\text { server. } \\
\text { 6. It should not be limited to open LMS, AIS, Email. For example, like Saturday and } \\
\text { Sunday, the server must remain open }\end{array}$ \\
\hline
\end{tabular}




\begin{tabular}{|l|l|}
\hline $\begin{array}{l}\text { 7. We recommend that systems such as LMS and AIS must be fully activated to make it easier } \\
\text { for students to learn. }\end{array}$ \\
\hline
\end{tabular}

According to Scott Young[32], to study the complex skill, cognitive resources such as attention, memory, effort, etc. must be learned from the various exercises. The example, learn to operate the LMS, the students must have computer skills and English skills. These skills can not be faster to learn, mastering these skills requires frequent practices that are drill methods. The student must be focused on a single aspect. When the student had attention to learn computer skills, the student also must understand the English language. On the other hand, the student become to know what the learning media that they love to use when they have studied.

The benefits

\begin{tabular}{|c|c|}
\hline $\begin{array}{l}\text { The main } \\
\text { participant }\end{array}$ & $\begin{array}{l}\text { - I prefer to learn face-to-face } \\
\text { - The existence of LMS and AIS helped me } \\
\text { - The LMS is very helpful to study that I can download lecture notes or PPT. } \\
\text { - this tool is very useful to upload and download the lecture notes. } \\
\text { - LMS and AIS are very helpful and simplified learning systems. } \\
\text { - LMS helped me in the learning process. If I have to collect assignments, I just open the } \\
\text { - FMS and upload it and don't need to find a lecturer for the collection process. }\end{array}$ \\
\hline Management & $\begin{array}{l}\text { - I don't think there is any advice, because everything is good enough } \\
\text { - It is hoped that the teaching and learning system will be more effective and active again } \\
\text { - My suggestion is that academic services with blended learning will always be better } \\
\text { - More enhanced } \\
\text { - to be further improved for fluency in learning and teaching. } \\
\text { - The service is very good and satisfying. } \\
\text { - I was quite satisfied with the features provided } \\
\text { - LMS and AIS are very helpful for students in sending assignments }\end{array}$ \\
\hline Entrepreneur & $\begin{array}{l}\text { - It is very good and improved to make it easier for students } \\
\text { - LMS, AIS provided very helpfully } \\
\text { - Continue to improve services to be even better. } \\
\text { - Hopefully, this blended learning academic service can run objectively } \\
\text { - using LMS and AIS is very helpful. Students can communicate with lecturers through LMS } \\
\text { and ask questions about things that are not understood. } \\
\text { - Hopefully, blended learning academic services can help the needs of students } \\
\text { - Hopefully, in the future, this blended learning academic service can further assist students in } \\
\text { doing assignments }\end{array}$ \\
\hline
\end{tabular}


According to the participant said: "For me, LMS is very effective and efficient because it is not bound by time and place" and "LMS helped me in the learning process. If I have to collect assignments, I just open the LMS and upload it and don't need to find a lecturer for the collection process", etc. Most of the students prefer to study with blended learning because this method is very helpful to upload the task or read the lecture notes so they can study effective and efficient at the outside face-to-face hours.

\section{Conclusion}

Blended learning is a means of transferring knowledge that is appropriate for Shanti Bhuana Institute, a campus located in Bengkayang, one of the underdeveloped districts in West Kalimantan, as a way to improve the quality of human resources. The relatively minimal quality of Bengkayang human resources, although it has been stated by the Ministry that Bengkayang has been eliminated from underdeveloped areas, requires appropriate knowledge transfer improvements. On the other hand, the knowledge transfer process is greatly influenced by the technology applied in learning. Why is blended learning appropriate to be applied to this campus? Blended learning applies e-learning (through a virtual world) and face-to-face learning as the main learning. Initially, the majority of students were still accustomed to face-to-face learning, which is traditional learning, so they were not used to getting their information via the internet. Likewise, this is supported by their local wisdom, namely the availability of nature in providing food so that they are accustomed to the instant culture.

Blended learning facilitates the transition of the face-to-face learning process commonly used by students when they are still in school to e-learning which educates them to be active in learning. Likewise, the application of blended learning requires continuous training (drill method) so that they become familiar with the use of computers, ICT, and so on. This research only applies in Bengkayang especially Shanti Bhuana Institute, because the application of blended learning is influenced by local wisdom of the Dayak tribe in Bengkayang and student learning styles.

The blended learning strategies as knowledge transfer are very helpful for the student in Bengkayang, especially in Shanti Bhuana Institute. The finding of this study only presents strategies of knowledge transfer in Shanti Bhuana Institute, 
because implementing this strategy must pay attention to local wisdom, the majority of the student's learning style. The blended learning strategies as knowledge transfer in Shanti Bhuana Institute are drill methods, implantation of the learning method, with a focus on learning style, local wisdom of the student.

\section{Acknowledgments}

Thankful the researches to Shanti Bhuana Institute which allowed researching on the campus and thank you to for the participant and the others who have helped to finish this study. 


\section{References}

[1] Ali Alammary, Judy Sheard, and Angela Carbone. 2014. Blended learning in higher education: Three different design approaches.

[2] Badan Pusat Statistik Kabupaten Bengkayang. 2019. Statistik Kesejahteraan Rakyat Kabupaten Bengkayang 2019. Bengkayang. Retrieved from https//bengkayangkab.bps.go.id

[3] Michelene T H Chi, Mirloi Bassok, Matthew W Lewis, Peter Reimann, and Robert Glaser. 1989. SelfExplanations: How Students Study and Use Examples in Learning to Solve Problems.

[4] Ricardo Chiva and Joaquín Alegre. 2005. Organizational learning and organizational knowledge towards the integration of two approaches. Manag. Learn. 36, 1 (March 2005), 49-68. DOI:https://doi.org/10.1177/1350507605049906

[5] Ricardo Chiva, Rafael Lapiedra, Joaquín Alegre, and Sandra Miralles. 2018. Organizational learning and knowledge management: A prospective analysis based on the levels of consciousness. In The Palgrave Handbook of Knowledge Management. Springer International Publishing, 85-103. DOI:https://doi.org/10.1007/978-3-319-71434-9_4

[6] Harry Collins. 2010. Tacit and Explicit Knowledge. The University of Chicago Press.

[7] John W. Creswell. 2013. Qualitative Inquiry and Research Design: Choosing Among Five Approaches (3rd ed.). SAGE.

[8] Roy José DeCarvalho. 1991. The Humanistic Paradigm in Education. Humanist. Psychol. 19, 1 (March 1991), 88-104. DOI:https://doi.org/10.1080/08873267.1991.9986754

[9] Michael G Degroote and Nick Bontis. 2001. Assessing knowledge assets: a review of the models used to measure intellectual capital.

[10] John Girard and JoAnn Girard. 2015. Defining knowledge management: Toward an applied compendium. Online J. Appl. Knowl. Manag. 3, 1 (2015), 20.

[11] Donald Hislop. 2010. Knowledge management as an ephemeral management fashion? J. Knowl. Manag. 14, 6 (October 2010), 779-790. DOI:https://doi.org/10.1108/13673271011084853

[12] Nicholas Haambokoma and Milingo Tomaida Kasonde Ng'andu, Farrelli Hambulo. 2013. The Contribution of Behavioral Theories of Learning to Education. Zambia J. Educ. 4, (2013), 58-74. DOI:https://doi.org/1996-3645

[13] Mona Aeysha Khalid. 2015. Educational Theories of Cognitive Development. J. Educ. Soc. Res. (January 2015). DOI:https://doi.org/10.5901/jesr.2015.v5n1p313

[14] Alice Y Kolb and David A Kolb. 2013. THE KOLB LEARNING STYLE INVENTORY 4.0 A Comprehensive Guide to the Theory, Psychometrics, Research on Validity and Educational Applications. Retrieved from www.learningfromexperience.com

[15] Gregorio Martín-de Castro, Miriam Delgado-Verde, José E. Navas-López, and Jorge Cruz-González. 2013. The moderating role of innovation culture in the relationship between knowledge assets and product innovation. Technol. Forecast. Soc. Change 80, 2 (February 2013), 351-363. DOI:https://doi.org/10.1016/j.techfore.2012.08.012

[16] Irmayanti Meliono. 2011. Understanding the Nusantara Thought and Local Wisdom as an Aspect of the Indonesian Education. TAWARIKH Int. J. Hist. Stud. 2, 2 (2011), 221-234.

[17] Pembangunan Daerah Tertinggal dan Transmigrasi Republik Indonesia Menteri Desa. 2019. Keputusan Menteri Desa, Pembangunan Daerah Tertinggal dan Transmigrasi Republik Indonesia. 
Bengkayang. Retrieved from https://www.jenepontokab.go.id/dokumen/KepmenDesaPDTT No 79 Thn 2019 ttg Penetapan DT yg terentaskan Thn 2015-2019 (Salinan).pdf

[18] Rosemary S. merriam, Sharon B., Caffarella. 1991. Learning in Adulthood. . Jossy-Bass, San Fransisco, 198-199. DOI:https://doi.org/doi.org/10.1177/074171369204200310

[19] Julie Money, Track Dinning, Sarah Nixon, Barbara Walsh, and Ceriann Magill. 2016. Co-Creating a Blended Learning Curriculum in Transition to Higher Education: A Student Viewpoint. Creat. Educ. 07, 09 (2016), 1205-1213. DOI:https://doi.org/10.4236/ce.2016.79126

[20] Clark Moustakas. 1994. Phenomenological Research Methods. SAGE, Thousand Oaks, California.

[21] David Nonaka, Ikujiro; Teece (Ed.). 2001. Managing Industrial Knowledge (1st ed.). SAGE Publications, London.

[22] Ikujiro Nonaka. 1995. The Knowledge-Creating Company. Jepang.

[23] Edna. Pasher and Tuvya. Ronen. 2011. The complete guide to knowledge management: a strategic plan to leverage your company's intellectual capital (1st ed.). John Wiley \& Sons, New Jersey.

[24] Michael Quinn. Patton. 2015. Qualitative Research \&amp; Evaluation Methods : Integrating Theory and Practice. (4th ed.). SAGE, Thousand Oaks, California.

[25] Pedro Soto-Acosta and Juan Gabriel Cegarra-Navarro. 2016. New ICTs for Knowledge Management in Organizations. Journal of Knowledge Management 20, 417-422. DOI:https://doi.org/10.1108/JKM-02-2016-0057

[26] Pedro Soto-Acosta, Simona Popa, and Daniel Palacios-Marqués. 2017. Social web knowledge sharing and innovation performance in knowledge-intensive manufacturing SMEs. J. Technol. Transf. 42, 2 (April 2017), 425-440. DOI:https://doi.org/10.1007/s10961-016-9498-z

[27] Paul Tosey. Bateson's Levels Of Learning: a Framework For Transformative Learning?

[28] Priska Vasantan. 2016. Blended Learning Method Based On Local Wisdom As A Spiritual Guidance Holy Trinity Community In District Bengkayang. JETL (Journal Educ. Teach. Learn. (2016). DOI:https://doi.org/10.26737/jetl.v1i1.33

[29] Priska Vasantan, Helena Anggraeni, Tjondro Sugianto, Management Science, High School, Shanti Bhuana, West Bengkayang, Indonesia Kalimantan, Priska@shantibhuana Ac Id, and Helena@shantibhuana Ac Id. 2016. Knowledge Transfer Based Local Wisdom by Learning Method Buddy Program In District Bengkayang. Int. J. Multi Disipline Sci. e-ISSN (2016), 2615-1707. DOI:https://doi.org/10.26737/ij-mds.v1i1.413

[30] Amelec Viloria, Ingrid Regina Petro Gonzalez, and Omar Bonerge Pineda Lezama. 2019. Learning style preferences of college students using big data. In Procedia Computer Science, Elsevier B.V., 461-466. DOI:https://doi.org/10.1016/j.procs.2019.11.064

[31] Amelec Viloria, Jenny Paola Lis-Gutiérrez, Mercedes Gaitán-Angulo, Abel Ramiro Meza Godoy, Gloria Cecilia Moreno, and Sadhana J. Kamatkar. 2018. Methodology for the design of a student pattern recognition tool to facilitate the teaching-learning process through knowledge data discovery (big data). In Lecture Notes in Computer Science (including subseries Lecture Notes in Artificial Intelligence and Lecture Notes in Bioinformatics), Springer Verlag, 670-679. DOI:https://doi.org/10.1007/978-3-319-93803-5_63

[32] Scott H. Young. 2019. Ultralearning: Master Hard Skills, Outsmart the Competition, and Accelerate Your Career. Harper. 